\title{
PRAGUE: THE NATIONAL PERCEPTION OF THE AREA ${ }^{1}$
}

Keywords: cultural heritage, Czech Republic, Prague, national identity, state identity Słowa kluczowe: dziedzictwo kulturowe, Czechy, Praga, tożsamość narodowa, tożsamość państwowa

\section{S u m m a ry}

The author analyzes the space of Prague presenting national perception of the city. It was registered as a UNESCO world heritage site. The author shows the process of changing Prague into a national symbol of Czechness. However, national movement increased national divisions between Czechs and German: in the 1880s separate promenades, coffee shops, and a university were established. During the First Czechoslovak Republic, the capital is mapped primarily in reference to the tradition of Charles IV and the Hussite movement. However, this tradition was modernized: Prague Castle as the seat of President T. G. Masaryk became the most important place in Prague. During Protectorate of Bohemia and Moravia, places associated with the Hussite tradition were "erased," but the symbolism of medieval Prince Václav (Wenceslas) was made into a symbol of Czech loyalty toward the Germans. Next phase of manipulation occurred when communist took power. National traditions no longer have an integrating and rallying function today.

\section{PRAGA - NARODOWA LEKTURA PRZESTRZENI}

\section{Streszczenie}

Autorka przedstawia narodową lekturę Pragi. Wpisano ją na Listę Światowego Dziedzictwa UNESCO. Czeski ruch narodowego odrodzenia wyznaczył w mieście miejsca najważniejsze dla jego tożsamości. Towarzyszył temu wzrost narodowych podziałów: w latach osiemdziesiątych XIX wieku powstały odrębne promenady, kawiarnie i uniwersytet dla Czechów i Niemców. W okresie pierwszej Republiki Czechosłowackiej stolica była mapowana w odwołaniu do tradycji Karola IV i ruchu husyckiego. Tradycja była jednak modernizowana: najważniejszym miejscem w Pradze stał się Zamek Praski jako siedziba prezydenta T. G. Masaryka. W okresie Protektoratu Czech i Moraw „wymazywano” tradycję husycką i manipulowano symboliką księcia Wacława. Ta mentalna mapa miasta miała zaangażować społeczeństwo czeskie do walki o hitlerowską Europę. Po lutym 1948 roku przestrzenią manipulowano w duchu komunistycznym. Obecnie narodowe tradycje (a także zabytki) nie spełniają funkcji integracji i mobilizacji.

\footnotetext{
${ }^{1}$ This article was written as part of the project Progres Q 22.
} 
It is no surprise that the first of the twelve items of tangible cultural heritage found in the Czech Republic and acknowledged to date was the historic core of the capital city of Prague, registered as a UNESCO world heritage site in $1992 .{ }^{2}$ Despite Prague sharing this position with the historic core of the mediaeval city of Český Krumlov, with its extensive Rožmberk Castle complex and chateau with a famous Baroque theatre, ${ }^{3}$ and the historic medieval core of the "Moravian Venice," Telč, with its Renaissance chateau complex and Renaissance and Baroque houses on the square, ${ }^{4}$ the value of Prague on the list - one of the primary indicators of success - naturally exceeds the cultural and heritage value of a small town in South Bohemia and a small town in South-West Moravia. In spite of their architectural-artistic uniqueness, Český Krumlov (a UNESCO world heritage site since 1992) and Telč (a UNESCO world heritage site since 1992) are simply unable to compete against the national-political importance of the metropolis of the Czech lands; or with its identification, integration, and representative importance.

Let us not forget that historic Prague actually became a symbol of Czech patriotism during the time of transformation of Czech national efforts into a national movement, that is, from the 1860s. According to Czech beliefs at the time, other Czech towns would not have existed without Prague, hence the city was regularly called the heart and head of the Kingdom. The Czech metropolis was regularly portrayed as a queen in medieval clothing. ${ }^{5}$

Prague was not simply an organically grown unit of monuments, buildings, and localities - as some classify cultural heritage ${ }^{6}$ - but chiefly an augmented ground plan of Czech history. When the "masses" of Czech society adopted national history - the key condition for the origin of a modern nation ${ }^{7}$ - which logically led to an even more personal relationship with the town and supposedly evoked emotions in every conscious Czech (or even, in the broader context, Slav). According to the national press, these emotions were how a Czech could be distinguished from a foreigner. While a foreigner was supposedly capable of rationally appreciating only the excellence of the architectural and artistic work

${ }^{2}$ http://whc.unesco.org/en/list/616; https://cs.wikipedia.ogr/wiki/Sv\%C4\%9BtovC3\%A9_d\% C4\%9Bdictv\%C3\%AD (acc. 05.09.2017); Věra Kučová, Světové kulturní a př́rodní dědictví UNESCO (Praha: Národní památkový ústav, 2009), 117-128.

${ }^{3}$ http://www.unesco-czech.cz/cesky-krumlov/predstaveni/ (acc. 05.09.2017).

${ }^{4} \mathrm{http}: / /$ www.unesco-czech.cz/telc/predstaveni/ (acc. 05.09.2017).

${ }^{5}$ Blanka Soukupová, "Praha - mýtus českého a zlatého slovanského města: Mobilizace národní identity nebo protiněmecký konstrukt?,” in Etnické komunity. Vyjednávání pozice v majoritě, eds. Dana Bittnerová, Mirjam Moravcová (Praha: FHS UK, 2012), 164-165.

${ }^{6}$ Věra Kučová, op. cit., 55.

${ }^{7}$ Miroslav Hroch, V národním zájmu. Požadavky a cíle evropských národních hnutí devatenáctého století ve srovnávací perspektivě (Praha: Nakladatelství Lidové noviny, 1999), 19. 
of the historic core of Prague as an "interesting antique," the view of the same site reputedly immediately evoked historic reminiscence in Czechs. The fact was emphasized by the Czech awareness of the contrast: the famous past was supposedly placed in counterpoint to the dismal present that eventually resulted in the strong emotions of Czechs. This was accurately expressed in 1882, when the Czech-German polarization of Prague was at its peak, as we read in Národní listy, a new Czech daily: "Bring a German or foreigner to our city for the first time and he will admire the beauties of this city; bring a Slav here for the first time, and he will weep." 8

These highly positive feelings of national importance versus the downfall of the country were to be naturally unavailable to the German or German Jewish minorities living in Prague since the eleventh ${ }^{9}$ and tenth ${ }^{10}$ century respectively. We may primarily link the key constants that formed the framework of the thought processes of Czech society from the beginning of the Czech National Movement to the awareness of Slavic communality and the declaration of this communality - the Slavic Family - from the last third of the nineteenth century. The Czech National Movement utilized Herder's reasoning: the Slavs should chiefly be peaceful, welcoming, and musically talented. From Czech Germans and Jews - and Austrian police bodies - Slavism meant dangerous separatist tendencies. However, it seems that in view of growing Czech confidence, Czechs ceased to consider Slavism a superior and, on the contrary, endeavored to lead the Slavic Family themselves; or, more precisely, they dreamt of such endeavor. Czechs not even linked the awareness of Slavic communality with the knowledge of individual Slavic nations and their mentalities (people had the greatest delusions about Tsarist Russia).

The relationship with Czech Germans and Jews - often Germanized - underwent great changes in comparison to the beginnings of the National Movement. Even though the German culture remained a great example for the middle classes, the Czech stereotype of the German as the enemy became a significant nation-forming factor during the 1860s. While Czech society strove to achieve the same rights for Czechs and Germans, who lived in the Czech lands and protested the suppression of Czech in the 1860s, the Germans appeared in the role of the malicious enemy in the 1880s. Czech Germans were to be the worst kind of Germans, while the Germans in the German empire were considered more nationally moderate and reasonable. Czech Jews found themselves in the middle of a conflict between two distinctive national identities: the Czech

\footnotetext{
8 "Slovanská Praha," Národní listy, no. 276 (1882): 1.

${ }^{9}$ Antonín Boháč, Hlavní město Praha: studie o obyvatelstvu (Praha: Státní úřad statistický, 1923).

${ }^{10}$ Tomáš Pěkný, Historie Žido̊ v Čechách a na Moravě (Praha: Sefer, 2001), 11-12.
} 
and Czech-German. Even now, we naturally may encounter a specific residue of anti-German hatred, particularly from the oldest generation of Czech society, even though it is particularly reinforced by their memories of the Second World War, when the Czech nation was under real threat.

Literary historian Vladimír Macura points out that the Jungmann list of Prague emblems was very limited: it only included Vyšehrad, reputedly the oldest seat of Czech princes, the Vltava River, Charles Bridge, and White Mountain, where the ill-fated battle of the Bohemian estates against the Habsburgs occurred in 1620. In the 1860s the Jungmann list was expanded to include Týn Church, the city's main church since Hussite times, Vyšehrad, ${ }^{11}$ Prague Castle (mainly its Vladislav Hall, which had borne witness to the most important national gatherings since the sixteenth century, and White Mountain ${ }^{12}$ by Prague. ${ }^{13}$ The Czech "perception" of Prague, the metropolis of the Czech lands, and its surrounding area were understandably different to the German perception. Czech society highlighted the areas that were linked to key events in our own history; regardless whether these were positive like Vyšehrad and Prague Castle or negative like White Mountain. Whether the places in Prague applied to medieval Czech statehood was also important. In the case of Vyšehrad - joined to Prague in 1883 - it mattered that the suburb was distinctively Czech (according to the nationality of the population). Czech society chose an exceptional natural formation (the Vltava River) because this river actually links the most important places in the Czech lands, it passes important castles and simultaneously links rural areas in the Czech lands with the capital city. The very emotional relationship to the Vltava River as a Czech national river persists to this day. On the contrary, the national perception of the city at the time did not accept Malá Strana, in one fifth populated by Germans, the traditional Jewish quarter of Josefov, or certain streets with German associations and institutions like Na prríkopě/Am Graben street. However, even the peripheries of the city were deemed uninteresting for the national perception of the city, as these hosted the socially weaker population. The importance of the peripheries was emphasized only in the image of socialist Prague, which promoted a controlled reduction in the importance of the center as the site of the capitalist elite.

The Jungmann list was expanded in May 15, 1868 with the laying of the cornerstone for the symbolic building of the National Theatre,${ }^{14}$ whose importance

${ }^{11}$ Emanuel Poche, Prahou krok za krokem (Praha: Panorama, 1985), 223.

${ }^{12}$ Jakub Pavel, "Národní kulturní památka Bílá hora, bojiště a letohrádek Hvězda s oborou," in Bílá hora, národní kulturní památka, eds. Jakub Pavel, František Kavka, Josef Polišenský, Stanislav Pánek, Marie Vorličková (Praha: Olympia, 1969).

${ }^{13}$ Vladimír Macura, Znamení rodu. České obrození jako kulturní typ (Jinočany: H\&H, 1995), 180.

${ }^{14}$ Otto Urban, Česká společnost 1848-1918 (Praha: Svoboda, 1982), 230-231. 
increased in the 1880 s by the establishment of the National (Národní) Avenue on what used to be Ferdinand Avenue, with the national Slavia Café in Lažanský Palace - opened in 1884 - with a view of the Vltava River, the Castle, Malá Strana, where one can find a picture of Slavia, the Mother of the Slavs. ${ }^{15}$ It was the water of the Vltava River that reflected the buildings fundamentally linked to the Czech past and present. The Vltava River merged the cultural heritage with the natural heritage. Naturally, the areas excluded from the emblems of Czech Prague were the parts of the city inhabited and preferentially used by wealthy Prague Germans and Jews until the Second World War, who preferred the German culture: mainly Př́kopy, the promenade of the Prague Germans from the 1880s, parts of Nové Město, ${ }^{16}$ and also Bubeneč ${ }^{17}$ during the First Republic. These parts received new names in the "Slavic" and "Czech" style after the Second World War; for instance, the German Casino became the Slavic House (Slovanský dům), the New German Theatre became Smetana's Theatre.

However, the other purpose of this text is to analyze the relationship between the national, political, and state representation and the cultural heritage represented by the historic core of Prague, from the beginning of the Czechoslovak Republic in 1918 until 1992, when the capital city of the Czechoslovak Federation became the capital city of the ethnically homogenous Czech state.

With its intention to democratize society, bring up and educate people to the benefit of the state and the national collective, with its activeness, efforts to abandon provincialism, and contagious optimism, Masaryk's First Republic designated as the axes of its memory the times of Charles IV, under whom the Czech medieval state had achieved its greatest prosperity, the Hussite Era as the most famous era of Czech history in national mythology, the National Revival movement, ${ }^{18}$ and finally, the legionnaire tradition. On the other hand, the Baroque monuments, as a reputed reminder of the Czech counter-reformation

${ }^{15}$ Blanka Soukupová, Hedvika Novotná, "Kavárna, kavárníci a kavárenští hosté. Několik poznámek k fenoménu pražských kaváren,” Journal of Urban Ethnology, no. 8 (2006): 75; Karel Holub, ed., Velká kavárna Slavia (Praha: Ars Bohemia: Holub \& Altner: Nakladatelství Jan Hovorka, 1998).

${ }^{16}$ Gary B. Cohen, Němci v Praze 1861-1914, trans. Jana Madlerová (Praha: Univerzita Karlova v Praze, Nakladatelství Karolinum, 2000), 83-85, 99.

${ }^{17}$ Blanka Soukupová, "Pražská společnost středních vrstev v letech 1930-1938. K perspektivám mezietnického soužití na území jednoho státu," in idem, Lidé města, vol. 6. Město a jeho kultura (Praha: Institut základů vzdělanosti Univerzity Karlovy, Nadace Ethnos, 1994/1996), 68.

${ }^{18}$ Blanka Soukupová, "Praha - tradiční česká a nová státní metropole: mýtus a identita. K roli mýtů jako součásti ideologie nového češství a českoslovenství," in Mýtus - "realita" - identita. Státní a národni metropole po první světové válce, Urbánní studie, vol. 3, eds. Blanka Soukupová, Miroslav Hroch, Harald Christian Scheu, Zuzana Jurková (Praha: Fakulta humanitních studií Univerzity Karlovy v Praze, 2012), 12, 19, 24, 25. 
and Austrian loyalty ${ }^{19}$ were eliminated from positive national-political interests and protection. Czech public opinion perceived its cultural heritage not only in culture but also in nature. The state focused especially on the Prague Castle and the Sokol movement; ${ }^{20}$ not by chance: the state was establishing its army at the time and was forced to overcome Czech distrust toward repressive institutions and anti-militaristic attitude of the Czech labor movement, considerably reinforced by the tragedies of the First World War. The portrayal of Prague as the Mother of Cities, the head of the country, ${ }^{21}$ nation, the queen, potentially "Vienna" as the dethroned queen, ${ }^{22}$ was also reinforced. With the help of extensive investments and modifications, the Prague Castle was to be the most important symbol of the new state, of Czechoslovak and national identity, ${ }^{23}$ permeated by the indisputable charisma of the Czechoslovak President, as a monument to the former Czech greatness and simultaneously the past residence of the rejected Habsburgs. And it was Masaryk's presence at the Castle that was to figuratively eliminate the difference between those inside and outside of the castle, to open the Castle to ordinary citizens, teach them to make a "pilgrimage" to the Castle and experience this walk as an exceptional and pleasant event. ${ }^{24}$ Let us add that eyewitness memories evidence that this opportunity to democratize turned inward to successfully adopt and determine the accord between historic and current importance. Traces of any Czech ambivalent relations with the Prague Castle from the time of Austria-Hungary disappeared and the Castle (like the personality of Masaryk) became a more-or-less successful integrating element of all the nationalities and minorities living in Czechoslovakia. However, the new ambitions were not only linked to the Castle but also to Wenceslas Square, the center of the revolution on October $28,{ }^{25}$ which was to open from Můstek through a victory gate, according to a never implemented project to monumentalize

${ }^{19}$ Zdeněk Hojda, Jiří Pokorný, Pomníky a zapomníky (Praha, Litomyšl: Paseka, 1997), 28-32.

${ }^{20}$ Blanka Soukupová, "Klub za Starou Prahu, památky a pamět. Reflexe starobylosti a krásy města v české společnosti koncem 19. a ve 20. století,” in Město - identita - pamět’, eds. Blanka Soukupová, Hedvika Novotná, Zuzana Jurková, Andrzej Stawarz (Bratislava: Zing print, 2008), 21.

${ }^{21}$ Blanka Soukupová, "Praha - tradiční česká a nová státní metropole: mýtus a identita. K roli mýtů jako součásti ideologie nového češství a českoslovenství,” 22, 11.

${ }^{22}$ Antonín Balšánek, "Praga caput Patriae," Národní listy, no. 166 (1918): 1; Alois Žípek, "Hlava svobodného státu," in Praha v obnoveném státě československém, ed. Václav Vojtišek (Praha: Rada hlavního města Prahy, 1936), 3-4.

${ }^{23}$ Blanka Soukupová, "Klub za Starou Prahu, památky a pamět'. Reflexe starobylosti a krásy města v české společnosti koncem 19. a ve 20. století," 21.

${ }^{24}$ Blanka Soukupová, "Česká národní identita a Praha. Sakrální a profánní místa ve velkoměstě," in Sfera sacrum et profanum w kulturze wspótczesnych miast Europy Środkowej, eds. Adam Koseski, Andrzej Stawarz (Warszawa, Pułtusk: Polskie Towarzystwo Etnologii Miasta, 2004), 51.

${ }^{25}$ Antonín Klimek, Říjen 1918. Vznik Československa (Praha, Litomyšl: Paseka, 1998), 194-196 . 
the Square by the prominent architect Pavel Janák. The pavement in the center of the square was to be bordered by statues of important people from Czech history; the most political square was to become an expression of Czech primacy in the new state. The currently undefined modern urban space was to become a dominant space, along with the Castle, intended for the most important state celebrations. ${ }^{26}$ The smaller area of the historic Old Town Square, enclosed within a wall of houses, was no longer sufficient for high state-political ambitions. This site of the Municipal Authority with a monument to Hus (1903-1926), where manifestations had frequently overflowed during the First Republic, was now used for acts of piety rather than large manifestations. ${ }^{27}$

During the Protectorate of Bohemia and Moravia and, partly, the so-called Second Republic, what gained prominence was the area of Old Town Square, with its Tomb of the Unknown Soldier from 1922 (removed in 1941), ${ }^{28}$ as the center of Czech resistance in the first months of the occupation. ${ }^{29}$ The square was later intentionally used by Nazi Germans and collaborating Czechs for manifestations of loyalty of the Czech nation to the empire, just like they used Wenceslas Square and the National Theatre. ${ }^{30}$ While the Czech Resistance retained its First Republic attitude to cultural heritage, ${ }^{31}$ the motif of the Czech landscape gained importance under the Protectorate. ${ }^{32}$ Czech groups of collaborators endeavored to nationalize the emblems of the historic heritage of Prague and subordinate them to the concept of Czech life under the protection of the German Empire in a new Europe. Medieval Prince Václav (Wenceslas), the Czech protector and patron, was promoted as a symbol of Czech loyalty toward the Germans. However, from the Czech viewpoint, the monuments of Hussite Prague had to be removed - the Art Nouveau monument to Master Jan Hus on Old

\footnotetext{
${ }^{26}$ Blanka Soukupová, "Václavské náměstí - proměny pražského korza v moderní době," in Československé město včera a dnes: Každodennost - reprezentace - výzkum, eds. Barbora Vacková, Slavomíra Ferenčuhová, Lucie Galčanová (Červený Kostelec, Brno: Pavel Mervart, Masarykova univerzita, 2010), 24-25.

${ }^{27}$ Blanka Soukupová, "Praha - tradiční česká a nová státní metropole: mýtus a identita," 26.

${ }^{28}$ Jaroslav Láník, Jan Vlk, eds., Dějiny Prahy II (Praha: Ladislav Horáček - Paseka, 1998), 393.

${ }^{29}$ Detlef Brandes, Češi pod německým protektorátem. Okupační politika, kolaborace a odboj 1939-1945, trans. Petr Dvořáček (Praha: Prostor, 1999), 107; Blanka Soukupová, "Mýty Prahy v období protektorátu Čechy a Morava a jejich významy," in Mýtus - "realita" - identita. Národní metropole v čase vyvlastnění, kolaborace a odporu, Urbánní studie, vol. 5, eds. Blanka Soukupová, Róża Godula-Węcławowicz (Praha: Fakulta humanitních studií Univerzity Karlovy v Praze, 2013), 16.

${ }^{30}$ Jaroslav Láník, Jan Vlk, eds., op. cit.; Blanka Soukupová, "Václavské náměstí - proměny pražského korza v moderní době,” 28-29; Blanka Soukupová, “Mýty Prahy v období protektorátu Čechy a Morava a jejich významy," 36-37.

${ }^{31}$ Blanka Soukupová, "Mýty Prahy v období protektorátu Čechy a Morava a jejich významy," $30-31$.

${ }^{32}$ Blanka Soukupová, "Klub za Starou Prahu, památky a pamět'," 22.
} 
Town Square was covered in a Nazi flag - as well as the statue of Moses and Rabbi Lowe. ${ }^{33}$ Monuments of the Přemyslid and Habsburg periods were becoming more popular. However, the monuments of this era were simply presented as evidence of sensible, peaceful, and fruitful German-Czech cooperation in the past. Prague Castle, presented mainly as the residence of state president Emil Hácha, was to symbolize the specific sovereignty of the Czech nation within the Empire, however a sovereignty conditional on the absolute loyalty to Nazi Germany. ${ }^{34}$ This corresponded with the celebrations of Imperial Protector's birthday held at the Castle. It was no coincidence that the motif of Prague Castle under threat from the hand of the Russian Bolshevik primitive was portrayed on the best-known protectorate poster by Antonín Hradský (1944).

The socialist regime returned to the monument list of the First Republic, with the exception of the monuments of Legionnaires and generals linked to the First Republic. However, the socialist regime interpreted their importance in the spirit of the new ideology. The regime emphasized the plebeian origins of the revivalists and their indisputable social awareness. In the case of Hussite monuments' renovation, socialism made sure that they became symbols of the mass people's social movement, the culmination and fulfilment of which was to be the post-February establishment. ${ }^{35}$ The socialists placed new monuments for labor and communist movements, ${ }^{36}$ and they presented the Castle as the residence of the working-class president Klement Gottwald. ${ }^{37}$ The new socialist city emerged from the creation of new squares and the gradual de-politicization of Wenceslas Square along with its transformation into a shopping and entertainment center. ${ }^{38}$

${ }^{33}$ Vojtěch Šustek, "Nacistická kariéra sudetoněmeckého historika," in Josef Pfitzner a protektorátní Praha v letech 1939-1945, vol. 2, eds. Alena Míšková, Vojtěch Šustek (Praha: Scriptorium 2000), 15.

${ }^{34}$ Blanka Soukupová, “Mýty Prahy v období protektorátu Čechy a Morava a jejich významy,” 38.

${ }^{35}$ Blanka Soukupová, "Místo husitské tradice v moderní české společnosti: základní kámen národní identity," in Pamět' - národ - menšiny - marginalizace - identity I., Urbánní studie, vol. 6, eds. Blanka Soukupová, Helena Nosková, Petr Bednařík (Praha: Fakulta humanitních studií Univerzity Karlovy v Praze, 2013), 28-34; “"Teprve komunisté uskuteční Libušino proroctví.' Praha v mytologii reálného socialismu," in Blanka Soukupová, Mýtus - "realita” - identita. Socialistické metropole v zápasech o novou př́tomnost a vizi št'astné budoucnosti, Urbánní studie, vol. 8, eds. Blanka Soukupová, Daniel Luther, Peter Salner (Praha: Univerzita Karlova v Praze, Fakulta humanitních studií, 2014), 11, 17-19.

${ }^{36}$ Blanka Soukupová, "Klub za Starou Prahu, památky a pamět'," 24-25; Blanka Soukupová, “"Teprve komunisté uskuteční Libušino proroctví'. Praha v mytologii reálného socialismu,” 19-21, 23-27.

${ }^{37}$ Blanka Soukupová, “'Teprve komunisté uskuteční Libušino proroctví.' Praha v mytologii reálného socialismu."

${ }^{38}$ Blanka Soukupová, "Václavské náměstí - proměny pražského korza v moderní době,” 32, 36-42. 
After the Velvet Revolution, the historic core of Prague became the first of the Czech "Twelver Wonders of the World." However, the ambitious political establishment began to perceive Prague differently than Masaryk's Czechoslovakia; Prague was considered the center of Christian Europe,${ }^{39}$ a paradox in the predominantly secularized Czech society, whose Europeanisation was very weak. Even though a number of inaccessible areas of Prague Castle were opened under the first post-November president, Václav Havel, ${ }^{40}$ the way citizens of the First Republic identified with the Castle disappeared, so the Castle only witness crowds of tourists today. The strong competitors to become sites of Czech memory and cultural heritage invaded the increasingly commercialized city, which welcomed the tourist trade: the always open gargantuan shopping centers, luxury shops, multiplex cinemas, and water parks.

\section{Conclusion}

During the First Republic, Czech cultural heritage appeared differently than it does today; its national and state-integrating significance was most important. For example, rather than as a unique artistic-architectural monument, the famous panorama of Hradčany was considered a magnificent diadem of Prague as the royal city, the metropolis of the former medieval state, later demeaned by the Austrian and Austro-Hungarian monarchy that, still, was unable to remove its royal magnificence. The list of First Republic cultural heritage sites was adopted by the Protectorate even though it reduced it to Hussite, Sokol, and legionnaire monuments; hence, the symbols of Czech military tradition. However, manipulation of cultural heritage remained part of political mobilization by the collaborating government even in this period. The return to the national tradition - especially Hussite and Revivalist - was unique during the period following the Second World War within the terms of the socialist political camp. We can describe it as an elaborate manipulation of the awareness of a threat to the Czech nation during the Protectorate, the traditional fear of Germany in modern Czech society, and also as an endeavor to transform the Czech tradition of Slavic empathy into a tradition of Czechoslovak-Soviet partnership. After 1989, we witnessed a distancing from national traditions and our own history. What now seems to be the most important is the historic and artistic value of cultural heritage, to the detriment of its identity-strengthening and integrating significance.

${ }^{39}$ Blanka Soukupová, "Praha v čase 'návratu do Evropy.' Česká a státní metropole mezi pamětí a vizemi budoucnosti," in Mýtus - "realita" - identita. Národní metropole v čase "návratu do Evropy,” Urbánní studie, vol. 9, eds. Blanka Soukupová, Andrzej Stawarz (Praha: Fakulta humanitních studií Univerzity Karlovy v Praze, 2015), 28.

${ }^{40}$ Jaroslav Láník, Jan Vlk, eds., op. cit., 508. 


\section{References}

Balšánek, Antonín. “Praga caput Patriae.” Národní listy, no. 166 (1918): 1.

Boháč, Antonín. Hlavní město Praha: studie o obyvatelstvu. Praha: Státní úřad statistický, 1923.

Brandes, Detlef. Čěsi pod německým protektorátem. Okupační politika, kolaborace a odboj 1939-1945, trans. Petr Dvořáček. Praha: Prostor, 1999.

Cohen, Gary B. Němci v Praze 1861-1914, trans. Jana Madlerová. Praha: Univerzita Karlova v Praze, Nakladatelství Karolinum, 2000.

Hojda, Zdeněk, et Jiří Pokorný. Pomníky a zapomníky. Praha, Litomyšl: Paseka, 1997.

Holub, Karel, ed. Velká kavárna Slavia. Praha: Ars Bohemia: Holub \& Altner: Nakladatelství Jan Hovorka, 1998.

Hroch, Miroslav. V národním zájmu. Požadavky a cíle evropských národních hnutí devatenáctého století ve srovnávací perspektivě. Praha: Nakladatelství Lidové noviny, 1999.

Klimek, Antonín. ̌̌íjen 1918. Vznik Československa. Praha, Litomyšl: Paseka, 1998.

Kučová, Věra. Světové kulturní a prírodní dědictví UNESCO. Praha: Národní památkový ústav, 2009.

Láník, Jaroslav, et Jan Vlk, eds. Dějiny Prahy II. Praha: Ladislav Horáček - Paseka, 1998.

Macura, Vladimír. Znamení rodu. České obrození jako kulturní typ. Jinočany: H\&H, 1995. Národní listy, no. 166 (1918): 1.

Pavel, Jakub. "Národní kulturní památka Bílá hora, bojiště a letohrádek Hvězda s oborou." In Bílá hora, národní kulturní památka, eds. Jakub Pavel, František Kavka, Josef Polišenský, Stanislav Pánek, Marie Vorličková. Praha: Olympia, 1969, 3-4.

Pěkný, Tomáš. Historie Židi̊ v Čechách a na Moravě. Praha: SEFER, 2001.

Poche, Emanuel. Prahou krok za krokem. Praha: Panorama, 1985.

"Slovanská Praha." Národní listy, no. 276 (1882): 1.

Soukupová, Blanka. "Česká národní identita a Praha. Sakrální a profánní místa ve velkoměstě.” In Sfera sacrum i profanum w kulturze wspótczesnych miast Europy Środkowej, eds. Adam Koseski, Andrzej Stawarz. Warszawa, Pułtusk: Polskie Towarzystwo Etnologii Miasta et al., 2004, 41-60.

Soukupová, Blanka. "Klub Za starou Prahu, památky a pamět'. Reflexe starobylosti a krásy města v české společnosti koncem 19. a ve 20. století.” In Město - identita - pamět', eds. Blanka Soukupová, Hedvika Novotná, Zuzana Jurková, Andrzej Stawarz. Bratislava: Zing print, 2007, 14-32.

Soukupová, Blanka. "Místo husitské tradice v moderní české společnosti: základní kámen národní identity?" In Pamět' - národ - menšiny - marginalizace - identity I. Urbánní studie, vol. 6, eds. Blanka Soukupová, Helena Nosková, Petr Bednařík. Praha: Fakulta humanitních studií Univerzity Karlovy v Praze, 2013, 9-40.

Soukupová, Blanka. "Mýty Prahy v období protektorátu Čechy a Morava a jejich významy." In Mýtus - "realita" - identita. Národní metropole v čase vyvlastnění, kolaborace a odporu. Urbánní studie, vol. 5, eds. Blanka Soukupová, Róża Godula-Węcławowicz. Praha: Fakulta humanitních studií Univerzity Karlovy v Praze, 2013, $13-47$. 
Soukupová, Blanka. "Praha - mýtus českého a zlatého slovanského města: Mobilizace národní identity nebo protiněmecký konstrukt?" In Etnické komunity. Vyjednávání pozice v majoritě, eds. Dana Bittnerová, Mirjam Moravcová. Praha: FHS UK, 2012, 163-186.

Soukupová, Blanka. "Praha - tradiční česká a nová státní metropole: mýtus a identita. K roli mýtů jako součásti ideologie nového češství a českoslovenství.” In Mýtus - "realita” - identita. Státní a národní metropole po první světové válce. Urbánní studie, vol. 3, eds. Blanka Soukupová, Miroslav Hroch, Harald Christian Scheu, Zuzana Jurková. Praha: Fakulta humanitních studií Univerzity Karlovy v Praze, 2012, 9-31.

Soukupová, Blanka. "Praha v čase 'návratu do Evropy.' Česká a státní metropole mezi pamětí a vizemi budoucnosti." In Mýtus - "realita” - identita. Národní metropole v čase "návratu do Evropy." Urbánní studie, vol. 9, eds. Blanka Soukupová, Andrzej Stawarz. Praha: Fakulta humanitních studií Univerzity Karlovy v Praze, 2015.

Soukupová, Blanka. "Pražská společnost středních vrstev v letech 1930-1938. K perspektivám mezietnického soužití na území jednoho státu.” In Lidé města, vol. 6. Město a jeho kultura. Praha: Institut základů vzdělanosti Univerzity Karlovy, Nadace Ethnos, 1994 (1996), 66-92.

Soukupová, Blanka. “Teprve komunisté uskuteční Libušino proroctví.' Praha v mytologii reálného socialismu." In Mýtus - "realita" - identita. Socialistické metropole $v$ zápasech o novou př́tomnost a vizi št'astné budoucnosti. Urbánní studie, vol. 8, eds. Blanka Soukupová, Daniel Luther, Peter Salner. Praha: Univerzita Karlova v Praze, Fakulta humanitních studií, 2014, 9-52.

Soukupová, Blanka. "Václavské náměstí - proměny pražského korza v moderní době." In Československé město včera a dnes: Každodennost - reprezentace - výzkum, eds. Barbora Vacková, Slavomíra Ferenčuhová, Lucie Galčanová. Červený Kostelec/ Brno: Pavel Mervart/Masarykova univerzita, 2010, 11-47.

Soukupová, Blanka, Novotná, Hedvika. "Kavárna, kavárníci a kavárenští hosté. Několik poznámek k fenoménu pražských kaváren.” Journal of Urban Ethnology, no. 8 (2006): 73-90.

Šustek, Vojtěch. "Nacistická kariéra sudetoněmeckého historika.” In Josef Pfitzner a protektorátní Praha v letech 1939-1945, vol. 2, eds. Alena Míšková, Vojtěch Šustek. Praha: Scriptorium, 2000, 8-38.

Urban, Otto. Česká společnost 1848-1918. Praha: Svoboda, 1982.

Žípek, Alois. "Hlava svobodného státu." In Praha v obnoveném státě československém. Praha: Rada hlavního města Prahy, 1936, 3-7. 